\title{
Social Innovation for the Welfare of the Community
}

\author{
K. VARGA
}

University of Miskolc, Faculty of Economics, Institute of Management Sciences, varga.krisztina@unimiskolc.hu

Abstract. The aim of the study is to highlight the focal points that are potentially activating factors in social innovation efforts in the most disadvantaged areas. The study examines certain social initiatives in the Nyírbátor district, with particular emphasis on the efforts promoting community welfare. The study primarily presents the results of qualitative interviews as part of a doctoral research. The examined cases play an important role in the management of the unfavourable processes in the region, and their adaptation as good practice can support the catching-up process. The study identifies the main groups of aspects that, in addition to structuring the case descriptions, also facilitate comparability of good practice. Documentation based on defined criteria supports the adaptation process, which is critical to the successful implementation of social innovation efforts.

\section{Introduction}

Theoretical background to the concept of innovation appeared in Schumpeter's Theory of Economic Development in 1912. Schumpeter considered the entrepreneurial activity to be the essence of the business cycle, which leads to imbalances through innovation, and the subsequent spread of innovation and adaptation to the economy creates a new equilibrium. He combined the theory of innovation with the theory of creative destruction and defined the entrepreneur as creating a new product or service by combining existing factors in a novel way.

Ogburn [1] interprets a particular combination or modification of cultural elements in society as an endeavour to renew society. The prominent role of social initiatives was also examined by Dénes Gábor in 1970 [2], who analyzed scientific, technical, biological and social innovations and concluded that technical innovations were significantly divided from social innovations. According to him, the predominance of technical innovation has caused disproportion in the innovation process, as efforts to increase social welfare have fallen behind and have been pushed to the periphery. In his interpretation, social innovation is a comprehensive framework program, which primarily is not a parallel initiative to technical innovation, but a "reform" that controls and regulates all innovation [2]. The theoretical definition of social innovation emphasizes the need for innovation in all areas of life, and innovation initiatives must not be limited only to the technical and economic spheres [3]. In the 1970s, the concept of social innovation received particular attention (Rosanvallon, Fournier), emphasizing the role of social transformation in problem solving [4]. Social initiatives are novel solutions to people's problems [5]. Zapf [6] and Bagnasco and Sabel [7] emphasize the fundamental importance of cooperation, innovative and cooperative social task-solving (in terms of social and economic innovation). 
International Journal of Engineering and Management Sciences (IJEMS) Vol. 5. (2020). No. 1 DOI: 10.21791/IJEMS.2020.1.39

\section{Social innovation processes}

Profound research of the process of social innovation is a relevant task [8] for two reasons:

- on the one hand, social innovation efforts have multiplied and are increasingly addressing social challenges,

- on the other hand, the process of social innovation is in itself a change that will result in unimaginable new solutions not yet known.

The social innovation process can be identified along two polarities [8]:

- incremental or radical change: as with technological innovation, the proposed change can take place within previously known frameworks (incremental innovation) or through efforts out of the frames (radical innovation),

- top-down or bottom-up initiative: The starting point for the innovation process is the person or group of people who will trigger the change process. If it is a researcher or a political decision maker, then the process is top-down, but if (typically) it is based on the involvement of people and small communities, the initiative is organized from below. Hybrid social innovation processes are created through a combination of top-down and bottom-up processes.

The process of social innovation can be described by the following interrelated sub-processes [9]:

- meeting the needs of society,

- changes in social relationships,

- mobilizing socio-political resources and access to them.

García et al. [10] identify social innovation as a broad-spectrum process the results of which are as follows:

- resources, services are provided to meet social needs,

- confidence builds up and activity supporting marginalized groups increases,

- social relations are changing, and transformation creates new governance measures.

Bacon et al. [11] identified three determining factors that explain the dynamics of the social innovation process:

- willingness to change (based on fear of threat or opportunity for innovation),

- efficient activation of (internal) resources available for change,

- effective achievement of available (external) resources for the implementation of the transformation process.

Resources (people, money, skills, and networks) in this interpretation represent the resources that provide positive feedback from the community for renewal.

The basic criterion of the social innovation process is that it should be a novel initiative. This does not necessarily mean a completely new solution, but a novel combination of previously wellfunctioning routines that meet the occurring social needs, thus creating new skills. In the case of 
International Journal of Engineering and Management Sciences (IJEMS) Vol. 5. (2020). No. 1 DOI: 10.21791/IJEMS.2020.1.39

social needs, it is an extremely important criterion how urgent the need is and how sustainable the proposed solution is. Social innovation is not a linear but a spiral process due to feedback. The level of occurance, the sector where the initiative can be observed, and the examination of further developing (generating) opportunities are basic questions to be answered.

Social innovation is a dynamic process. Feedback and temporal relevance are of key importance in certain activities of social innovation.

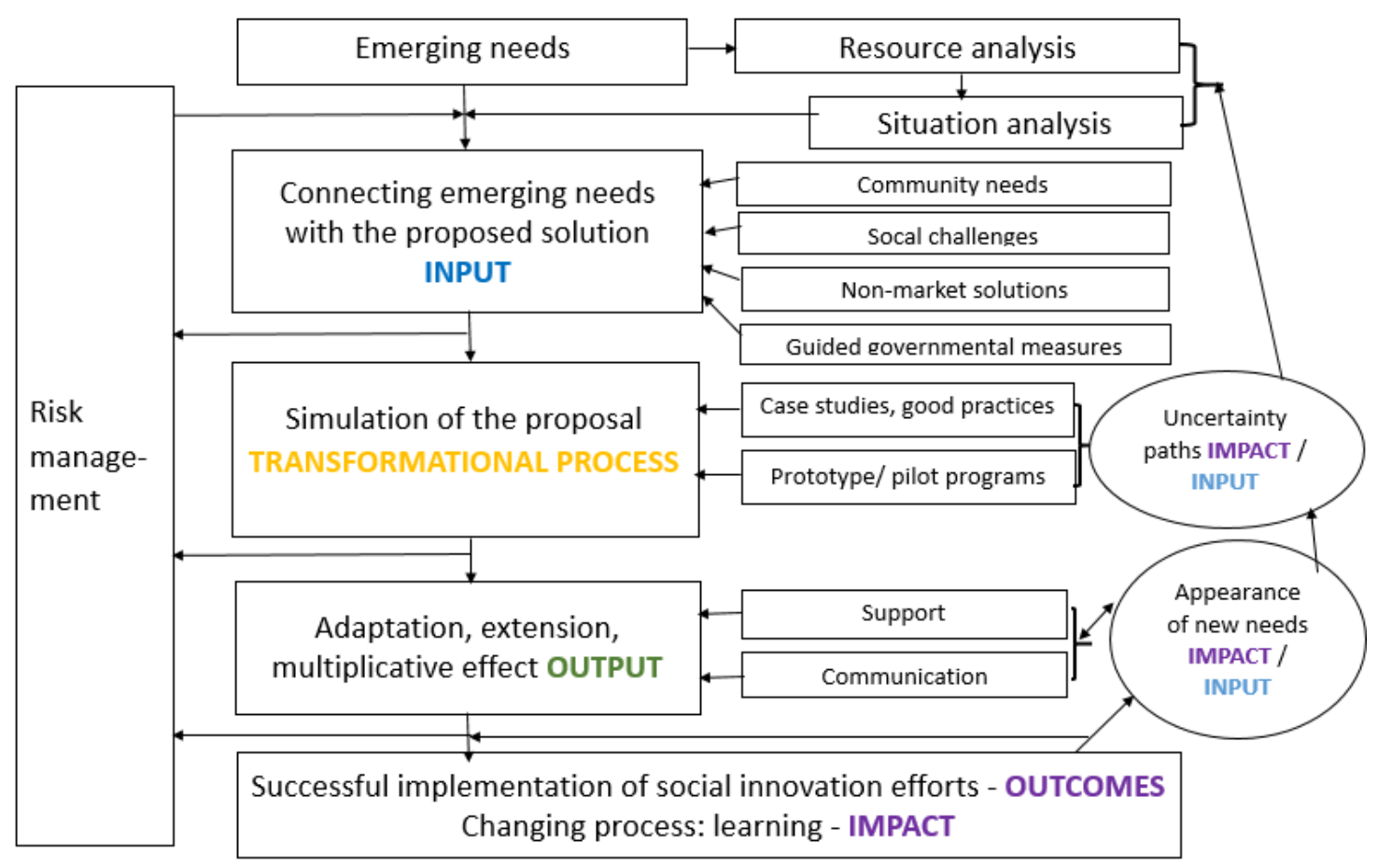

Figure 1 The dynamic process of social innovation

Source: own compilation

(based on [12])

The initial step in the process of social innovation is the examination of emerging needs, the satisfaction of which requires prior resource analysis and related situation analysis. Connecting community needs, social challenges, non-market solutions and guided governmental measures, as well as novel responses to them, means the input factors in the social innovation process. Efforts are basically not market based solutions, but they are initiatives that also result in the renewal of the society that form the community in the long run. Risk management can also be seen as an input factor at this stage. The following step is to examine the possible and proposed solution with the help of the Falcon model, which involves the introduction of prototypes and/or pilot programs after examining case studies and good practices. In our previous research [19], we have come to the conclusion that it is advisable to support the phase involving the creation of social innovation with the help of IT solution because of the huge amount of data to be processed, i.e. the introduction of a support system is required. As a result of this methodological study, we chose to 
use fuzzy logic. The fuzzy system is able to handle multiple data types at a time and can be perfectly combined with decision trees, which is the basis of our model. After reviewing several neuro-fuzzy models, the Falcon method was chosen, which is capable of learning both parameter and system rules. In the Falcon feed-forward network, the fuzzy weights characteristic of the input and output membership functions are built in neurons, so that instead of one there are three hidden layers, two of which are currently interpreted [20]. This is the most uncertain phase of the social innovation process, which is constantly challenging those concerned. After practical compliance, social efforts become adaptable, then extension takes place and multiplicative effect appears. At this point in the process, the supportive atmosphere (resources, institutions, political and social framework conditions) and proper communication are important factors. At this stage of the process, either new needs can emerge or new efforts can be proposed to the community with the help of well-functioning communication channels. Successful implementation of the social initiative leads to a changing process (learning) as a result. During the process, it is necessary to consider and evaluate the risks, to develop strategies for their reduction or elimination. Following the successful implementation, new needs emerge that can be met by the socially innovative community along the above process. Therefore, social innovation is a dynamic process that results in social learning through feedback loops and constant risk assessment.

\section{The role of social innovation efforts in catching up}

The social challenges that require long-term solutions (eg. unemployment, migration, disadvantaged areas) require innovative social cooperation. Social innovation is a necessary step for development and promoting competitiveness, where the role of innovators is essential. Innovators are members of the local community or, more broadly, of society, who respond to their needs through new or novel solutions to meet the demands of social challenges. During my research, I will pay special attention to the most disadvantaged areas and their opportunities to help them catch up. For the deprived settlements of the Nyírbátor district, it is necessary to introduce innovative partnerships, identify and meet local needs, involve citizens in local decisions, and analyze the impact of social innovation efforts on living standards.

The district of Nyírbátor (Szabolcs-Szatmár-Bereg county) is ranked 13th in the list of districts to be developed, with three towns (Nyírbátor, Nyírlugos, Máriapócs) and 17 municipalities belong to it. The dynamic catch-up and development of Nyirbátor is largely determined by the relatively high proportion of disadvantaged, mainly Roma population. The town's getting onto the path of long-term growth clearly depends on the overall management and social integration of the disadvantaged population. The main challenges of the examined settlement (ageing, migration of disadvantaged citizens) require innovative co-operation between the local government, businesses and NGOs. 


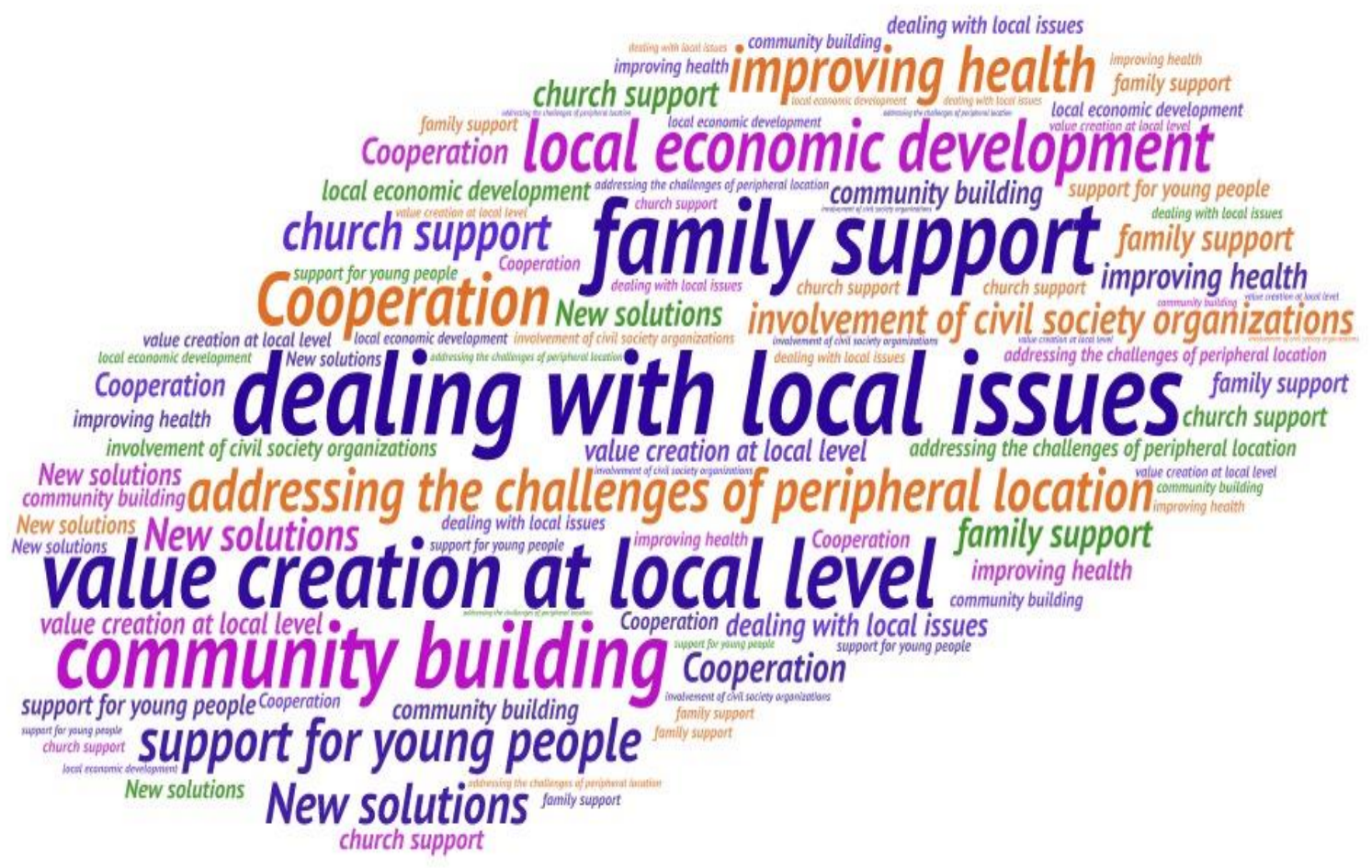

Figure 2 Main challenges of social innovation

Source: own compilation

Addressing the fallback of regional imbalances and creating opportunities for catching up in peripheral regions is a major challenge. In addition to the technological and scientific innovations that prevailed until the 1980s, innovations appeared that primarily aimed at increasing the wellbeing of society and a given community. The peripheral settlements and their need for catching up came to the forefront. Social disparities, diminishing opportunities for catching up and lower levels of peripheral competitiveness require solutions both collectively and individually, which should help catch up and reduce disparities [13]. Activities of social innovation, the innovative ideas that can be interpreted at local and community level, have played an important role in this catching-up process. It should be emphasized that besides the process of social innovation, scientific, technical and economic innovation does not become superfluous, because together they can enhance the well-being of the given community. The relationship between technical and economic innovation and social innovation is described by Farkas as "the latter process being the boundary condition, the space and the medium of the former" [14].

There is a correlation between the economic output of a given region and its capacity for innovation [15]. However, innovation (finding new and innovative solutions) needs to be interpreted more broadly. In line with social changes, the European Union is paying greater attention to the connections of social innovation than before.

There is a need for a paradigm shift, and in addition to the ever increasing investment in technical and natural science $R \& D$, there is a growing need for new and innovative solutions to the social and economic problems of a given small community (settlement, region). 


\section{Research: Method and Results}

The study of Nyírbátor district (Szabolcs-Szatmár-Bereg county) was based on the analysis of available statistical data, i.e. TEIR and KSH (HSCO: Hungarian Central Statistical Office) and expert interviews. Qualitative interviews with mayors and civil and economic experts show that the Nyírbátor district includes disadvantaged settlements that face significant challenges. Social innovation efforts play a key role in addressing these challenges, and the present study examines how they can be successfully implemented.

The research consists of two parts:

- establishment and analysis of a statistical database,

- expert interviews and their analysis.

This study is part of a doctoral dissertation examining issues of measuring social innovation in the Nyírbátor district. Accordingly, this study presents a small section of the doctoral study, which is primarily a case study based on qualitative interviews.

The main groups of questions in semi-structured interviews are:

- general organizational information,

- social innovation as an own concept,

- implemented social innovations,

- planned social innovation efforts,

- regional cooperation (and its opportunities).

\subsection{Main challenges of the Nyírbátor district}

The LAU 1 (formerly NUTS 4) level of the European statistical system is the district level. The 290/2014. (XI. 26.) Government Decree (decree on the classification of beneficiary districts) on the disadvantaged districts and the districts to be developed identifies beneficiary districts as:

- Beneficiary district: its complex indicator is less than average of all district complex indicators,

- Districts to be developed: districts with the lowest complex indicator, where $15 \%$ of the country's population lives.

According to the above classification, the districts with the lowest complex indicator, in which $10 \%$ of the cumulated population of the country live, are districts to be developed with a complex program. A complex indicator is a composite indicator that is determined by socio-demographic, housing and living conditions, the local economy and labour market, and infrastructure and environmental indicators.

As of January 1,2015, the number of districts to be developed by a complex program determined by the District Development Index/ (HCSO) is 36, typically located in the peripheral part of the country. Every second resident of Szabolcs-Szatmár-Bereg County lives in a district to be developed with a complex program. 
International Journal of Engineering and Management Sciences (IJEMS) Vol. 5. (2020). No. 1 DOI: 10.21791/IJEMS.2020.1.39

The main challenges of Nyírbátor district:

- $\quad$ social challenges: emigration, aging, disadvantaged groups, inequality between levels of education,

- economic challenges: housing conditions, unemployment, financial resources, expertise,

- political challenges: government transparency, independence of decisions, commitment.

\subsection{Focal points of social innovation efforts in the Nyírbátor district}

In the disadvantaged settlements of the Nyírbátor district, social innovation appears as a model and determines the success of the catching-up process.

The efforts are basically responsive to local needs, addressing the challenges of the population through creative problem solving and innovative co-operation, and result in a higher standard of living and well-being.

During the qualitative study four critical areas were identified:

- promoting the employment of disadvantaged groups,

- strengthening the attachment to the place of residence,

- reducing inequalities in education,

- $\quad$ support for local economic development.

$\begin{array}{lll}\text { NEED/CHALLENGE } & \text { BEST PRACTICE } & \text { SETTLEMENT } \\ \text { improving employment } & \begin{array}{l}\text { Roma employment } \\ \text { program }\end{array} & \text { Nyírbátor } \\ \begin{array}{l}\text { increasing the attachment to the } \\ \text { place of residence }\end{array} & \begin{array}{l}\text { support for civil } \\ \text { organizations }\end{array} & \text { Máriapócs } \\ \text { reducing educational inequalities } & \text { Tanoda program } & \text { Nyírvasvári } \\ \text { local economic development } & \text { Dragon Race } & \text { Nyírbátor }\end{array}$

Table 1 Good practices for social innovation in catching up in the Nyírbátor district

Source: own compilation

\section{2. 1. Roma employment program (Nyírbátor)}

In 2015, a complex program was launched in Nyírbátor, the district center, to improve the living conditions of Roma communities. During its social innovation efforts, Nyírbátor identified interventions that integrated the infrastructure deficiencies of the residential areas, the labour market, education, health and other problems of the disadvantaged population. Within the framework of so-called soft interventions for the social integration of disadvantaged people, various labour market training, measures aimed at the employment of long-term unemployed and 
civil society development programs have been implemented. The novelty of the interventions was that the development of the programs was preceded by various professional forums, roundtable discussions (enterprises - municipalities - disadvantaged people) and open days. Socially innovative solutions have emerged that are based on real social dialogue and partnership, where the partnership goes beyond the usual forms and creates truly active thinking.

The complex program is being implemented within the ROMED/ROMACT program. From 2013 up to this date, ROMACT has been implemented in 170 municipalities, generating over 135.000.000 $€$ through inclusive projects, with an average investment of $25.000 €$ per municipality per year. In Hungary, 14 municipalities have been involved since 2013 in the project. Nyírbátor is one of them which town involved different stakeholders: vocational training institutions, representatives of Roma young people, employers, employment center, representatives of culture - institutions, churches, Roma population. The project is supported by the European Union.

In the field of employment, the following short-term objectives have been set:

- providing detailed information on training and professions to disadvantaged groups,

- presenting positive examples to disadvantaged groups,

- vocational training of members of disadvantaged groups, as required by employers,

- introducing mentoring among stakeholders,

- developing a talent management process among stakeholders,

- defining the framework conditions for a scholarship scheme.

In connection with the above objectives, the following long-term objectives have been set in the field of employment:

- ensuring the presence of Roma workers in all areas of the labour market,

- inclusion of open and inclusive employers to the program,

- providing a well-trained, motivated, disciplined and qualified workforce from members of disadvantaged groups.

\section{2. 2. Strengthening the attachment to the place of residence (Máriapócs)}

Strengthening the attachment the place of residence can be achieved through cooperation with non-governmental organizations, responding to the needs of their members and the mayor's role as an innovator. In Máriapócs the above criteria can be observed together. The basis of success is the support for NGOs. The 12 non-governmental organizations in the settlement of 2130 people were organized according to different needs and challenges of the population:

- support for disadvantaged groups,

- information on health issues,

- support for children,

- consideration of local needs.

In the spring of 2017, the settlement opened a Civil House, which can be used free of charge by the associations. After the renovation of the old mansion from the tender funding, the Civil House 
serves as an office, a venue for meetings and events, and a club for NGOs. Association meetings are regularly held in the house. In order to maintain a good relationship with the NGOs, the mayor of the city organizes a community-building event in January called 'Pig Slaughter of Civilians', where members of the NGO's participate. At these events, 100-150 members of the association spend the day learning about each other's needs in more detail. The Civil House can also be used by city residents as a venue for celebrating various events (engagement, graduation).

\section{2. 3. Reducing the educational inequalities of disadvantaged children (Nyírvasvári)}

Nyírvasvári also implements social innovation initiatives through one of its NGOs called Vasváriak Vasváriért Közéleti Egyesület. The organization, operating since 2006 and serving a higher public education need, has implemented several programs in the past decade. The main focuses of the programs were:

- public education,

- health promotion,

- employment of disadvantaged workers,

- strengthening the attachment with the place of residence ,

- reducing educational inequalities.

The project was supported by The Social Renewal Operational Program (in hungarian: TÁMOP). The program was established in 2007 within the framework of the Hungarian National Strategic Reference Framework, New Hungary Development Plan, and serves the implementation of the Priority of Social Renewal in accordance with the European Union legislation and regulations. The program ran for 6 years, until 2013.

The educational opportunities of 37 disadvantaged young people were improved with the help of the Tanoda program, which included the catching up with subjects, organization of leisure and cultural programs and mentoring in 2010-2011.

The idea behind the Tanoda was to:

- integrate self-empowered young people into the active population of the municipality,

- increase the number of participants in secondary education programs, as well as promoting their occupation and matriculation opportunities,

- improve students' learning results and help them catch up.

Compared to the planned 35 students, the program helped 37 children during its operation.

Main results

1. Participated students in the program

2. Number of multiple disadvantaged students

3. Dropout rate from the Tanoda
Planned Data

Actual Data
35 people
$37+5$ people
27 people
29 people
3 people
1 people 
International Journal of Engineering and Management Sciences (IJEMS) Vol. 5. (2020). No. 1 DOI: 10.21791/IJEMS.2020.1.39

4. Failed students from the Tanoda

5. Participation in programs organized after study period

6. High school dropout rate among the students of the Tanoda

7. Percentage of students in post-secondary education or in vocational training

8. Participants of Tanoda whose results have

improved between input and output measurements
3 people

$65 \%$

$10 \%$

$50 \%$

$80 \%$

Table 2 Target groups of the Tanoda program, number of participants

1 people

$68 \%$

$0 \%$

$100 \%$

$100 \%$

Source: own compilation (based on qualitative interview with the project manager)

\section{2. 4. Dragon Race (Nyírbátor)}

The Dragon Race is an annual obstacle race with extreme obstacles in the Land of Dragons. Its location is Nyírbátor, the Dragon Wellness and Spa and its surroundings in the woods.

The purpose of the race is to create an opportunity for everyone who is attracted to this type of competition. The vision of the organizers is that the race will be internationally recognized and this type of sport will be established in Nyírbátor. The first race was held in Nyírbátor in the summer of 2017. The organizers, in cooperation with the city administration and the management of the local spa, decided to organize an event that had never been in the city before. The obstacle course was created in the spirit of the Spartan Race. The Dragon Wellness and Spa has the qualities that are ideal for such a competition. The second race was held in July 2018, and the number of participants were three times higher than the previous year. In 2019, two races were held. The initiative has now grown into Dragon Race \& ICE, a summer and winter obstacle race.

One of the highlights of the competition is the 'Cekker' race, where the 'registration fee' is food with long shelf life (flour, oil, pasta). The donations will be distributed to the families in need in the area. During the race, participants will run in apron and with a shopping trolley in short distance, which in itself draws attention to the program.

Results of the race so far:

2017: 1st Dragon Race

- race as the main program: 64 competitors, 23 volunteers (including photographers)

- other program: 'Cekker' race, Facebook page-group event creation, registration on sportkrono.hu,

2018: 2nd Dragon Race 
International Journal of Engineering and Management Sciences (IJEMS) Vol. 5. (2020). No. 1 DOI: 10.21791/IJEMS.2020.1.39

- one of the main programs of the Bátori Sport Day, a full-day program: 253 competitors, 65 volunteers (including photographers), special prizes: the oldest competitor, the competitor celebrating their birthday on the day of the race,

- other program: 'Cekker' race, 3 months Facebook campaign page-group event and advertising, Instagram page, YouTube channel, dragonracehun@gmail.com and launch of own website (www.dragonrace.hu), registration on sportkrono.hu, Dragon Ice registration on own site.

2019: New race: Dragon ICE Winter Dragon Race and new logo,

- race as the main program: 169 competitors, 60 volunteers (including photographers), the Dragon Race is added to the great running map (OCR Magazine).

\subsection{Social Innovation Initiative as Good Practice}

During the research I emphasized the analysis of social innovation efforts that can be interpreted as good practice. In my opinion, the novel cooperation between and within the municipalities serves as an example for other, sometimes disadvantaged, settlements. The presentation and recognition of local, regional and international experience and practice will be useful to both the giving and the receiving party. The former can broaden its knowledge of sustainability, while the latter can explore the challenges of adaptation and the opportunities offered by new structures. I studied new and innovative solutions, which I recorded in the form of a case study. Case studies allow good practices to be presented in a complex way, providing opportunities for adaptation, sustainable operation and effective implementation.

The above initiative (Dragon Race), as an example of good practice, provides direction after adaptation (eg. in the catching-up process) and its recording and dissemination in the system allows for further innovation.

Documentability guarantees transferability. There are principles of documentability to ensure that the identified case is truly an example of good practice. Good practice was documented along three main issues. The questions focused on general information, a descriptive presentation of the practice and an exploration of the reasons for good practice. This documentation principle allowed for a comprehensive analysis of the exemplary practice and for its success to be judged. Local initiatives can be implemented elsewhere, adapting to local conditions and practices. In many cases, it is noticeable that solutions applied in other organizations, municipalities or countries are not known in some regions, so it is extremely useful to record and disseminate good practices. 
International Journal of Engineering and Management Sciences (IJEMS) Vol. 5. (2020). No. 1 DOI: $10.21791 /$ IJEMS.2020.1.39

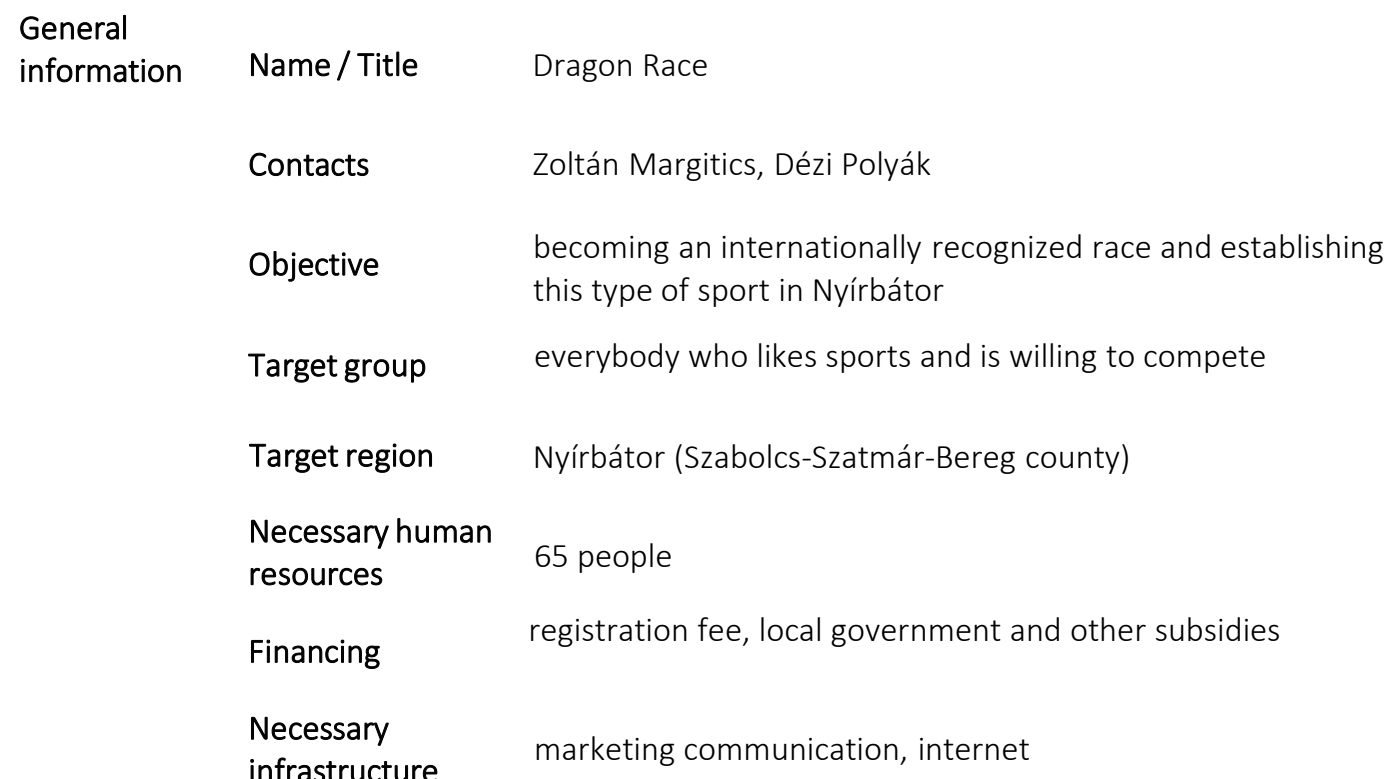

Realization

In cooperation with the city administration and the management of the local spa, 2017 saw an event that had never been before in the city. The Dragon Wellness and Spa has the features that are ideal for such a competition. By 2019, two races have been organized. This initiative has now grown into Dragon Race \& ICE, a summer and winter obstacle race.

Results, outcomes, future prospects

350 competitors, 70 volunteers, marketing campaigns, equipment necessary for implementation, carrying out the necessary trainings, and arranging cooperation with business partners, 'Cekker' Race (charity)

Problems and lessons learned

expertise, lack of volunteering, resistance of certain urban groups 
International Journal of Engineering and Management Sciences (IJEMS) Vol. 5. (2020). No. 1 DOI: 10.21791/IJEMS.2020.1.39

\section{Why is it good practice?}

As the center of one of the most disadvantaged districts,

Area-based approach

A bottom-up approach

Partnership approach

Innovation

Integrated approach

Publicity / Networking Sustainability

Transferability Nyírbátor takes a leading role in pursuing social innovation efforts

In addition to the opportunity for professional competitors, the primary goal is to involve Nyírbátor sports teams in the race, thus promoting team registrations. It is a networking place for local sports clubs.

Self-government (Nyírbátor), city-created Városfejlesztő és Múködtető Kft., Sárkány Wellness and Spa, multinational corporations with local presence in Nyírbátor, local companies, entrepreneurs, associations, NGOs, student organizations, volunteers

Involving the youth of Nyírbátor and its surroundings in the organization of the city program, thus encouraging them to the attachment to the city, increasing the role, attraction and image of the city as a tourist.

The individual measures and development programs are closely related. the competition made the city internationally known and emerged as a good practice transporter.

publication, website, thesis, online media

The project responds to real needs, adjusts to needs, and cooperates with the municipality.

Local factors, barriers and priorities can be identified as important factors. Framework conditions for improving living conditions at the local level will result in catching-up. The identification of stakeholders in the process, the role of communication (informing), the planning of financial resources, attempts to change attitudes and institutional background are all of particular importance.

Table 3 Nyírbátor - Dragon Race as good practice in social innovation

Source: own compilation

(based on [16] and [12])

\section{Conclusion}

When studying social innovation initiatives, the social benefit of innovative ideas that can be interpreted at local and community level and the role of community involvement in raising living standards are emphasized. New social practices and solutions aim at social change based on comprehensive, pre-planned, goal-oriented activities [17]. In addition to external negative stigma, the internal stigmatization process [18] arising from the need of the local population to be involved in local decision-making is a particular problem. 
International Journal of Engineering and Management Sciences (IJEMS) Vol. 5. (2020). No. 1 DOI: 10.21791/IJEMS.2020.1.39

For disadvantaged, deprived settlements, active participation in decision-making and the mobilization of civil society are key issues, one of the tools of which is to support social innovation efforts. The success of social innovation initiatives depends to a large extent on regional or local co-operation and networks, the promotion of which is an essential task for local governments in the region. Decision-making based on the involvement of local people is a paradigm shift in the functioning of local governments, which in itself is a social innovation.

In the case of the Nyírbátor district, communication and mutual learning between the local population, economic and political actors, as well as civil society organizations is crucial for the activation of internal potentials. In addition to the given environmental conditions as endogenous variables, supporting social innovation efforts and initiating novel collaborations are critical factors for successful catching-up processes.

\section{References}

[1] Ogburn, W. (1957): Cultural Lag as Theory. Sociology and Social Research, pp. 167174.

[2] Gábor, D. (1970): Innovations: Scientific, Technological, and Social, Oxford University Press

[3] Drucker, P. (1985): Innovation and entrepreneurship, Harper \& Row, Publishers, New York

[4] MacCallum, D. et al. (2012): Social Innovation and Territorial Development, Ashgate, 1st edition

[5] Whyte, W. F. (1982): Social Inventions for Solving Human Problems, American Sociological Review, Vol. 47, No. 1, pp. 1-13.

[6] Zapf, W. (1989): Über soziale Innovationen. Soziale Welt, pp. 170-183.

[7] Bagnasco, A. - Sabel, C. F. (ed.) (1995): Small and Medium-Size Enterprises, Pinter, London

[8] Manzini, E. (2014): Making Things Happen: Social Innovation and Design Design Issues, Volume 30, Issue 1, pp.57-66

[9] Moulaert, F. et al. (2005): Towards Alternative Model(s) of Local Innovation, Urban Stud. 42, pp. 1969-1990.

[10] García, M. et al. (2015): Social innovation and creativity in cities: A socially inclusive governance approach in two peripheral spaces of Barcelona, City, Culture and Society, 6, pp. 93-100.

[11] Bacon, N. et al. (2008): Transformers: How local areas innovate to address changing social needs, The Young Foundation, London: NESTA - National Endowment for Science: Technology and the Arts 
International Journal of Engineering and Management Sciences (IJEMS) Vol. 5. (2020). No. 1 DOI: 10.21791/IJEMS.2020.1.39

[12] Varga K. (2018): Methodological Challenges in Measuring Social Innovation: Literature review, In: Alina, Badulescu (ed.): Emerging Markets Economics and Business. Contributions of Young Researchers, Oradea University Press, pp. 273-276.

[13] Varga K. (2017): Társadalmi innováció és versenyképesség, (Social innovation and competitiveness), MultiScience - XXXI. microCAD, ISBN: 978-963-358-132-2

[14] Farkas J. (1984): Az innováció társadalmi-gazdasági akadályai (Social and economic barriers of innovation), Közgazdasági és Jogi Könyvkiadó, Budapest

[15] Kocziszky, Gy. - Veresné Somosi, M. (2016): Generating social innovation with knowledge engineering, Procedia - Socila and Behavioral Sciences 223, pp. 167-174.

[16] Szabó B. - Nagy F. P. (2014): Jó gyakorlat koncepció kidolgozása, a jó gyakorlat kiválasztás kritériumainak meghatározása (Concept of good practice, selection of the criteria of good practice), Regionális Forrásközpontok Országos Egyesülete, ISBN 978-615-5256-14-1

[17] Cajaiba-Santana, G. (2013): Social innovation: Moving the field forward. A conceptual framework. Technological Forecasting and Social Change, 82, pp. 42-51.

[18] Döringer, S. (2017): Is Social Innovation a Key to "De-Peripheralization"? Dealing with Challenges of Peripheralization on a Local Level, http://epub.oeaw.ac.at/0xc1aa5576\%200x0039109b.pdf

[19] Veresné Somosi M. et al. (2019): Step by Step for Social Innovation with Neuro-Fuzzy Modelling, European Journal of Economics and Business Studies 5. : 1. pp. 13-23.

[20] Retter Gy. (2006): Fuzzy, neurális genetikus, kaotikus rendszerek (Fuzzy, neural genetic, chaotic systems), Akadémiai Kiadó, Budapest 